\title{
Tender Fluid Machines
}

\section{Ania Chromik}

Fluids are vagabond stuff: they travel easily and are difficult to stop. Engulfing, volatile and clingy you can never be sure you have got rid of them for good as you might in the case of solids. Unlike solids which are cast once and for all and resist "separation of the atoms," liquids, according to Zygmunt Bauman, "neither fix space nor bind time" (2000, p. 2). Liquidity threatens to annihilate the boundary between Self and Other. Fluids defy my alleged autonomy and self-identity as a subject by reminding me of the permeability of my own body, of its vulnerability to collapse into other bodies and being collapsed into, and of the feeble conventionality and volatility of the very Self/Other division. Referring to the liminal potentiality of fluids, this article poses a series of openended questions problematizing this fragile division, at the same time liquidizing the formal distinction between theory and poetry and between speculation and corporeal praxis.

The fluid refuses to conform to the "laws governing the clean and proper, the solid and selfidentical" (Grosz, 1994, p. 195), and thus becomes an anti-thesis of self-contained subjectivity - this clearly delineated, coherent self that always stays "in itself" and does not mix with the world. Fluids seep, infiltrate, contaminate and flow; they threaten the self with disruptive disclosures of the constructedness of the unified body /self image, and thus pose a threat of throwing the self back into the undifferentiated and immanent experience of immediate continuity with the world. Elizabeth Grosz also claims that what is disquieting about fluidity is its cultural unrepresentability within prevailing philosophical models of ontology (1994, p. 195). While the broad field of body and identity studies (including corporeal feminism, queer studies, psychoanalysis, cultural materialism, etc.) have always acknowledged the significance of bodily fluids, the actual "messy" experience of insecure boundaries, seepages, leakages and engulfment is rarely referred to outside a frame which reduces the materiality of bodies to systems of signification.

If there is a potential for opening up a lateral and a more affirmative perspective on the liquidated subjectivity, it is, I believe, in experimenting on living organisms by appropriating and linking modes of experience that might seem radically speculative, yet capable of producing unexpected 
modes of affectivity. My paper therefore probes the juxtaposition of the Deleuzean-Guattarian concept of bodily assemblage with the metaphorical constructions of the pre-/anti-Cartesian fluid merger with the world represented by the humoural ${ }^{1}$ and grotesque body ${ }^{2}$ in order to speculate how it might affect the redefinition of becomings. The poetics which carries Deleuze's refiguring of the ontology of subjectivity in terms of temporary linkages, intensities and flows, as well as his notion of the body as an assembly of organs, discontinuous series of processes, and exchanges of corporeal substances and energies coincides with the discourse of the humoural body/self as described by the materialist critique of early modern discourse. Both concepts deconstruct the selfcontained, self-identical, cohesive subject and propose instead a mode of being that is open, fungible, trans-fluxible, permeable and volatile. The question is whether filtering the concept of the assemblage through the optics of another highly speculative theoretical construct would broaden the nomenclature of coming-together (rather than being), and thus whether assuming the volatile model has the power to render the experience of assemblage more palpable - palpable enough to move it to the realm of experience.

Bearing in mind that the "humoural corporeality" is a highly processed construct made up of the imagery used in the critique of the "contained" and "solid" modern subject, I have no intention of creating an intellectual argument here. I also misappropriate the idiom of the humoural body in a boldly nonchalant way, treating it as my literary material in an approach which is not philosophical but philological. Modern conceptualisations of pre-subjectivity interest me as digested poetic tropes; as accumulations of nouns and adjectives, reverberations, metaphors, metonymies, and so on. But it is precisely in this superficial appropriation of the poetics on which the critical discourse operates, that I see a certain dislocating potential for the thought experiment which this discussion aims to perform. So this paper should ideally open a mode of affectivity which creates new thought linkages and sensual experiences producing unexpected intensities. In this discussion, the emphasis on sense and taction, on the fleshy materiality of our own skins and organs, and, consequently, on affect, creates, what I see as a space for talking practice. It is my own bodily experience I experiment with, trying on this or that sensation, making miniscule movements towards this or that tingle, attuning myself to foreign feelings for a while, burrowing into this or that fragment of self/world relation. It has to be done this way, as Deleuze and Guattari point to the connection between the body without organs replacing organism and experimentation replacing interpretation (2003, p. 162). It is very much about investing the humoural / grotesque body with some palpable tenderness 
experienced in the body - in our bodies. Such an approach is also informed by the broad "practical" question behind the experiment - that is, how to make a Body without Organs - and an instruction which frames my speculations:

This is how it should be done: Lodge yourself on a stratum, experiment with the opportunities it offers, find an advantageous place on it, find potential movements of deterritorialization, possible lines of flight, experience them, produce flow conjunctions here and there, try out continuums of intensities segment by segment, have a small spot of new land at all times. (...) It is only here that the BwO reveals itself for what it is: connection of desires, conjunction of flows, continuum of intensities.

(Deleuze \& Guattari, 2003, p. 162)

There is still space within this prescription for looking for modes of affectivity which might facilitate the process on the level of lived embodiment. Now, what happens if I lodge myself in the virtual concept of the fluid humoural corporeality and use it as a booster to intensify the process? Just assemble these two concepts (that is, the Deleuzean assemblage and the humoural/grotesque body) and see what it does to both of them. Are they capable of forming a molecular connection which will change the quality of each of them in a new assemblage thus formed?

What makes the humoural/grotesque body interesting in this context is its capacity for creating a fluid and temporary conceptual machine with any model of embodiment which challenges the solid atomistic version of a separate body tightly contained within its skin and immune to any cross-contaminations with other bodies. Unlike a competent subject of modernity, it is construed as unable to keep itself safely "in" the body and therefore posing a threat to self-identity by spilling or leaking into the world and into the Other. It is marked with a potential re-immersion into the pre-subjective flux of experience dominated by the sensual and corporeal impulses of the undifferentiated Self/World union. The grotesque body especially - emphasising its bodily secretions, convexities and orifices, marked by interchanges and interorientations, as well as dismemberment and fusion with other bodies - represents a mode of corporeality which spills out of itself, absorbs the world and is itself absorbed by it. Described as "mobile and hybrid," "disproportionate, exorbitant, outgrowing its limits, obscenely decentred and off-balance" (Stallybrass \& White, 1986, p. 14), and never quite complete, it is a perfect epitome of "matter out 
of place" (Douglas, 2006). However, unlike the Kristevean notion of the abject (Kristeva, 1982), it is constructed as a celebration of pollution, openness, and lack of demarcation. The positive reconceptualisation of grotesque corporeality is about reaffirming its capability to create new modes of intersubjectivity - or rather temporary intersubjective states - through spillages, seepages, cross-contaminations, momentary interchanges, gaping wounds, merges, blurring, infections, flowing into the Other, swallowing the world and being swallowed by the world (see: Bakhtin, 1984, p. 317).

Whereas the Cartesian paradigm is often depicted as the solid foundation of the modern biomedical model in which the body is regarded as a mechanism/organism consisting of separate yet connected parts, the notion of the humoural body from before the scientific revolution evokes the sense of fluid and machinic connections, a microcosm within the macrocosm, of a human body immersed or mortised (as Owen Barfield has it) into the universe. In his relation to his environment, writes Barfield, the man of the Middle Ages was "rather less like an island, rather more like an embryo" (Barfield, p.78). Yet another fluid trope in the concept of the intrauterine sense of continuity with the world is the immanence and immediacy of experience identified with an asubjective or pre-subjective mode of being in the world (as opposed to the transcendental human/subjective experience mediated by boundaries and divisions implied by the famous Bataillean notion of the animalistic immersion in the world "like water in water" (Bataille, 1989, pp. $19,23,25)$. In a way, the animalistic continuity between self and world marked by a certain permeability which implies no distinct boundary between the inside and the outside (actually invalidating the very distinction) is a pervasive metaphor in humoural medicine and microcosm/macrocosm relations.

It is clear, writes Barfield about the speculative humoural man, "that he did not feel himself isolated by his skin from the world outside to quite the same extent that we do," with "each different part of him being united to a different part of the universe by some invisible threads" (Barfield, p.53). The connections and unities are not within the organism, but between organs, humours, and elements. The links would not be made so much between, for instance, one's liver and one's pancreas as the model of the organism suggests, but between one's liver, the element of air, and the planet Mars, with the skin boundary being much more provisional than we are used to it. The invisible humoural 
threads that connect the organs and the extracorporeal elements remind us of the fiber Deleuze and Guattari describe in One Thousand Plateaus:

A fiber stretches from a human to an animal, from a human or an animal to molecules, from molecules to particles, and so on to the imperceptible. Every fiber is a Universe fiber. A fiber strung across borderlines constitutes a line of flight or of deterritorialization.

(Deleuze \& Guattari, 2003, p 249)

Similarly, the humoral body appears to be better connected with the universe than it is with itself, in the sense that it does not produce an organism of interlocking and finite connections between organs within the skin, but rather machinic linkages circumventing the skin boundary, which intensify the potential of each individual fragment respectively. The humoural body connects to other bodies, animate and inanimate, linking organs and biological processes to material and cosmic objects while refusing to subordinate the body to a unity and central order of an organism. The humours, as the major conceptual frame of the pre-scientific Weltaschauung, are thus portrayed as a part of the world in the human being - the humours would wax and wane, depending on the workings of the elements. Unlike the tightly bound modern agent keeping the self safely "in" the body, the pre-modern man is characterised by the imagery of porous boundaries and exchanges of elements with the surroundings, with the surface of his body open to be permeated by fluids and air (Vigarello, 2005, p. 219). The model of constant pulsating flux, or, as Charles Taylor has it, "attunement" (Taylor, 1989, p. 155) construes man as responsive to the frequencies and rhythms of the elements (see: Vigarello, 2005, p. 219). Such a body can neither resist external pressures, nor can it contain its internal seepages. Gail Kern Paster, for example, describes it as a "porous and fragile envelope" (Kern Paster, 1993, p. 12),or a "semipermeable, irrigated container" in which humours rise and ebb (Kern Paster, 1993, p. 8). Among other things, this image informs numerous descriptions of an alleged fifteenth and sixteenth century's belief that water could ooze into the body through the pores of the skin and thus, by disturbing the fragile harmony of humours and inciting the liquid element in a human, mechanically alter bodily functions (see: Vigarello, 2005, p. 108).

It needs to be emphasized here that the point of this experiment is not just to show the correspondences between the fluid humoural sense of open boundary and the Deleuzean concept, 
but rather to see what these notion do to each other when linked. How do they transform, intensify and maximise each other? How does this assemblage widen our sensorium? I believe that the humoural body, intensified as a Deleuzean concept, is affected in an affirmative way: it now invites us to refigure the imagery of immersion, the microcosm-within-macrocosm image, that otherwise would suggest some higher-order machine endowed with a sense of bounded unity and telos. It encourages us to ask what happens if the transcendent organiser of the linkages between organs and elements in the humoural model, the divine guarantor of harmonia mundis, is replaced with the immanent sense of nothing more than the connections and productions that make it. The fleshy physicality of the humoural model (as opposed to the prevalent contemporary symbolic reading of the humours) provokes a question: what would happen if we began to think of the body-self not in terms of depth and organism but in terms of this kind of open boundary? How might this conceptual reorientation - a rejection of the experience of the self as a bounded organism, in favour of experiencing the skin asa semipermeable membrane - allow for a reconfiguration of the praxis of molecular connections of our organs with water, air, particles of food, fragments of tissues of other bodies? And, finally, how does the humoural body sensualise the Deleuzean concept? If the Body without Organs (BwO), as Deleuze and Guattari have it, is simultaneously an exercise or experimentation and a limit, something we never reach but are always already attaining (Deleuze \& Guattari, 2003, p.149-150), then this impossible process of becoming can only be facilitated by sensualisation. The operation of creating the momentary assemblage of the humoural body without organs embraces a tender affirmation and impossibility. It creates productive space by adding this extra fleshy, tangible, sensory dimension to the concept of assemblage.

The productive space opens up a dimension for fluid praxis: embracing the humoural model produces a sense of incorporation foreign to our sanitised conceptual-corporeal frame. And this is a physical sensation, starting with an invitation to play with the idea of such an experience - of a torsion into the Other, becoming more prone, more open, to intrusions and cross-contaminations. Morris Berman describes an attempt at recreating the humoural sense of participation of the Self and Non-Self at the moment of experience: "[M]y skin has no boundary. I am out of my mind, I have become my environment" (Berman, 1981, p. 72). Becoming one's environment in the humoural context is not mimicry, neither is it a total submergence of oneself into the Other. The merger will never be quite complete, it will never have been - it is not about claiming the Other, 
never devouring the Other, but rather a line pointing to a certain direction - always already in the movement that Deleuze and Guattari describe as dismantling the organism but not by killing it, but by "opening the body to connections that presuppose an entire assemblage, circuits, conjunctions, levels and thresholds, passages and distributions of intensity, and territories and deterriolizations" (Deleuze \& Guattari, 2003, p.149-150).

The metaphor of "becoming the environment" as merger that is never quite finished also characterizes the Bakhtinian grotesque body. It isis marked by the sense of an open boundary: not separated from the rest of the world - never closed and completed - emphasizsing those parts of the body through which the world enters or emerges, "through which the body itself goes out to meet the world" (Bakhtin, 1984, p. 26). Associations with Kristevean abjection are unavoidable: just like the abject, the grotesque body constantly poses a risk of blurring the frail construction of the Subject/Object distinction, haunting the self at the most vulnerable sites of its constructed boundaries - its openings and cavities, bodily pollution, reproductive functions, death. It also draws us "towards a place where meaning collapses" and is defined in opposition to its own corps propre (Kristeva, 1982, p. 2) - "one's own and clean proper body" (Roudiez, 1982, p. viii), ${ }^{3}$ that is, the classical body. ${ }^{4}$ While abjection is an obvious trope here, I believe that it might be more refreshing to probe for another, more affirmative perspective. ${ }^{5}$ The question I want to ask in this context is thus: what happens if the grotesque body, instead of being jettisoned, is celebrated? When I lose myself in it, and instead of experiencing abjection, I open myself to the productive aspect of this encounter? In other words, the body which, through its liminal character, questions transcendent subjectivity in a sensual way and constitutes a plane for the invasion of the semiotic - either by abjection or by tender embrace.

It is precisely the carnivalesque aspect of the grotesque body that invites this tender and celebratory openness rather than a reaction based on rejection and disgust. Bakhtin refers to the grotesque body as "the ever unfinished, ever creating body" (1984, p. 26) - the body that says yes to matter around it and freely creates connections and bonds. Abusive and devouring, never sealed off, never quite finished, always exceeding its limits in eating, drinking, defecating, urinating, copulating, getting pregnant giving birth and dying, the grotesque body is constantly creating new connections with the world and thus constituting a body without organs. The grotesque body is an ever-embracing body: its fleshy folds permeate and enfold the Other, but never in a penetrating 
way - there is no sense of interiority here, no desire based on depth, no lack that has to be filled by the Other. There is rather a playful interplay of surfaces and making machinic connections. The grotesque body devours and grows, bursts and shits, fucks and falls apart, outgrows itself and disrespects body boundaries, but, most importantly, it does it all out in the open; with no sense of hidden interiority, it "goes out to meet the world" (Bakhtin, 1984, p. 26). Bakhtin writes:

Eating, drinking, defecating and other elimination (sweating, blowing the nose, sneezing) as well as 'copulation, pregnancy, dismemberment, swallowing up of another body - all of these acts are performed on the confines of the outer world.

(Bakhtin, 1984, p. 317)

There is no sense of concealed depth behind the enfolding fold, there is nothing beyond what is already on top and exposed. The connections that the grotesque body makes with other bodies (human and inhuman) are not those of interiority and exteriority, but rather those of linkages, sequences of surfaces, alignments, intensities, redistributing organs and confluences. The surface becomes a plane open to flows and circulations of the machines that compose it. The emphasis is on the organs, not on the organism, and, most importantly, the grotesque body emphasises orifices, apertures and convexities: the open mouth, the genitals, the anus, the nose, the ear, the breasts. However, these are not gaping holes revealing the vast abyss of deep bodily interior. Rather, they constitute sites of cross-contaminations and open boundaries on the surfaces of intensity where the organs of one grotesque body merge with other organs and with the world:

All these convexities and orifices have a common characteristic; it is within them that the confines between bodies and between the body and the world are overcome: there is an interchange and an interorientation [...]. (Bakhtin, 1984, p.317)

The modus operandi of the grotesque body is the exchange of elements with the surroundings what might be theorised as a movement towards the Other, exposing one's openness in an act of tender vulnerability to the Other that is just about to flow into me. A constant flux, a seepage with no delineation and no sense of self. A body marked by incontinence with all the ambiguous implications of the word: by its inability to restrain and control its corporeal fluxes, by not being a tight container, not respecting demarcated subjectivities, and by its effluence, permeability and 
leakiness. (see: Paster 1993, p. 92) The body that secretes fluids, opens up, gapes with its orifices, refuses to stay within its borders, and seeps into the Other, contaminates the Other with itself and permeates the Other's boundaries. The infection spreads through the openings and transfers the properties of one into the other. The rupture that breaks through the continuity of the bounded self is what Kristeva describes as the symptoms of abjection: "a language that gives up, a structure within the body, a non-assimilable alien, a monster, a tumor, a cancer" (Kristeva, 1982, p. 2).The anxiety of an alien in the self $s$ an expression of the phobia of tenuous boundaries: the mingling and blending of identities. Abjection therefore exists in contrast to desire: the pre-objectal relationship precedes the emergence of the subject / object distinction necessary for the operation of desire in Lacanian psychoanalysis (see: Kristeva, 1982, pp. 10-11). But, again, the Deleuzean perspective lets me embrace an affirmative and productive dimension of this contamination which, if the obsessive stress on integrity is given up, can be perceived as alliance producing "assemblages capable of plugging into desire" (Deleuze \& Guattari, 2003, p.166) Assemblages are composed of heterogeneous elements, and the contagion happens not only on the level of breaking the continuity of a bounded entity, but is also connected to the heightening of the potential of the elements in play. The Deleuzian perspective, unlike the Lacanian one, does not associate desire with lack or something that exists outside the movement towards the Other, but as the immanent force which, "does not lack anything; it does not lack its object. It is, rather, the subject that is missing in desire, or desire that lacks a fixed subject; there is no fixed subject unless there is repression"(Deleuze \& Guattari, 2009, p. 26).

This entirely different concept of connections between bodies / fragment of bodies / material objects / biological processes / social practice forces the reconfiguration of the body understood in terms of its subordination to a higher organization. Instead of a body contaminating another body, the notion of an assemblage (or machine) opens up an image of provisional conjunctions and disjunctions of discontinuous elements, all of them at the same level: "An assemblage has neither base nor superstructure, neither deep structure nor superficial structure; it flattens all of its dimensions onto a single place of consistency upon which reciprocal presuppositions and mutual insertions play themselves out" (Deleuze \& Guattari, 2003, p. 90. What I think is crucial for the application of the Deleuzean-Guattarian frame to the grotesque body understood in terms of the exchange of elements or (affirmative) contamination, is that fragments of bodies can come together and align themselves to produce Deleuzean machines mainly through the mediation of 
bodily fluids and discharges from the orifices (see: Grosz, 1994, p. 120) In other words, the apertures and flows of discharge facilitate the machinic connections thus creating more and more series of becoming and lines of flight, new beginnings; the awesome "monstrous birth." The secretion therefore anticipates the assemblage through the enjoyment of opening to a whole world of intensities that are not my own, the joy of becoming Other. The grotesque body is a rhizome: the focus on bodily fluids and flows emphasises its quality as interbeing, intermezzo, always in movement, sending out liquid emissaries before the actual solidities of the organs can meet, thus reminding us of the excess of life, of the fact that we are always already more than the hermetic self we think we are. Bodily fluids sensualise the Deleuzean intermezzo and make it more tangible and the Bakhtinian perspective adds a sense of perpetual motion to it: this swarming, teeming ferment which denies the body any form of transcendence, subjectivity and property. Instead, there are only intensities that pass and circulate on its surface, fragments of bodies and objects, mutual insertions, flows, speeds, realignments, transmutations, pulsations, races, and tribes.

Once the fear of losing one's subjectivity and the anxieties over the firmness of body boundaries are replaced with the carnivalesque affirmation of pervasive proximity, it is impossible to determine who is feeling what, whose organs are affected at a given point in time. The softness of the moist encounter turns all machinic relations into lovemaking - whether it is making love, or eating, or surrendering to the bodily dispersion and pain. Deleuze and Guattari write about a "real making love" that constitutes a "body upon which what serves as organs is distributed according to crowd phenomena in Brownian motion, in the form of molecular multiplicities" (Deleuze \& Guattari, 2003, p. 30). The swarming sense of multiplicity requires a movement towards the humoural assemblage which can take place only through exposing my position in the act of tender hospitality, soft vulnerability to the Other-to-come/flow-into-me. I must construe my skin as a semipermeable membrane, open to cross-contaminations. I must reconfigure my skin as something that does not contain my body, but opens it to collapsing into and being collapsed into other bodies. I must reconfigure my digestive system, not as an abyss annihilating the food in a non-reciprocal act of consumption, but as a space for potential molecular connections in which particles of matter eaten form temporary alliances with particles of me, producing new qualities for the tasting and the tasted, the chewing and the chewed, the swallowing and the swallowed, the digesting and the digested. Replace abject revulsion with what Bracha L. Ettinger beautifully refers to as selffragilization (2009, p. 3). I must open myself to an affirmative encounter beyond the notion of 
desire defined as lack and depth - a matrixial interplay of surfaces, an elusive mobilisation of "erotic aerials" sensitive to transmissions and dispersions, forming a composite of porous transsubjectivity.

Shuddering with disgust is a response of a competent ego focused on continuous bodily control and self-containment, but to mobilise the productive aspect of this encounter which is always already infected with the virus of the Other, I must animate the loving celebration of the foreign body, the constant flickering of the Emersonian "bright foreigner, the foreign self" (Emerson 1984, p. 404) vibrating at a heightened state of vulnerability when the Other doesn't cling to itself, when the flesh of the Other might, like the grotesque Gargantuan body, erupt and get out of control, or enwrap and envelop me - when the Other's discharges and secretions might cling to me and pollute me, stain me and besmear me by leaving their fleshy mark. For our discrete, territorialised subjectivity governed by what Horkheimer and Adorno refer to as "[t]he effort to hold itself together," the contact with bodily fluids (of others and even one's own) is often marked with a fear of contamination epitomising identity as "[t] he fear of losing the self" (2002, p. 26). ${ }^{6}$ Instead of forcing myself to overcome this fear, I should surrender to my own fragility - vulnerable, trembling and curious; open myself to the contagion I might be scared of, when the lover her/himself is an open wound emanating volatile particles of him/herself which float and make machinic links with particles of me in temporary rivers and pools of sweat, saliva, ejaculate and tears. I must make a machine beyond the productive and sanitising discourse, acknowledge the cross-contamination of blood, milk and urine, even if homoeopathically diluted in the love reservoirs of our alchemically mixed bodily fluids. Remember, however, that they will never make a homogonous solution - the fusion can never be quite complete - it is never devouring or claiming the Other, but rather a liquid and pulsing movement pointing and outstretching itself towards the Other. There are flows and surges agitating me, surging and ebbing in my veins, in a sense of an open boundary - a combination of affirmation and the experience of the impossible.

An alchemical trope (which is obviously another humoural trope) which also becomes massively intensified when linked with the Deleuzean concept is the magical notion of some substances assuming the properties of others, which is characteristic of the discourse of alchemy and prescientific medicine: for example, the conviction that eating a lion's heart would enhance courage; or that eating pigeons would bring love; or a belief that just like "diamonds weaken the toadstone ..., 
topaz weakens lust" (Berman, 1981, p. 75); or the link between clear cold water and good eyesight. The connection between organs and elements of the machine (organic and inorganic, human and non-human) changes the quality of both elements on a molecular level as it maximises not only how the human organs can affect the world, but also what the other fragments of the assembly can do. In other words, the machine does not only enhance the consumer, but also the consumed: the courageous element in the eating human is strengthened, but at the same time the lion's heart would not be able to affect the world through human courage if it was not a part of this machine created in the act of eating. Get rid of the organising and hierarchising centre (in this case the harmonia mundis - the macrocosm/microcosm hierarchy), and the osmotic merger of the annihilating devouring turns into a flickering of surfaces, with many possible lines of flight, investments and the pure joy of interactions and becomings. As bodily fluids become vehicles for this machine - what is the temporary binder? Is it a liquid emissary of those molecular connections with particles of food and the inside of my mouth; a thread stretched towards the Other, or my saliva flowing into and being flown into the watery element in the food morsel? The digestive juices transport and transform the tiny elements of food, enwrapping them and changing their texture in this embrace. My blood changes its thickness and quality, and the now nutritive atoms reach a new level of agency in this flow.

Deleuze and Guattari stress that even in its masochistic productions the BwO is often "full of gaiety, ecstasy, and dance" (Deleuze \& Guattari, 2003, p. 150). It is the opposite of finding oneself - it is always about dismantling the self, but not in a self-destructive way - not by killing oneself - but by opening the body to connections and flows that draw new planes. For some reason, my intuitive grasp of "dismantling the self" is a pervasively fluid sensation of surrendering to being devoured, yet not consumed, and to the liquidations of the internal structure of the organism, all imbued with the poetics of ecstatically disruptive fluidity:

They open wide their mouth at me,

As a ravening and a roaring lion. 
I am poured out like water,

And all my bones are out of joint;

My heart is like wax;

It is melted within me. ${ }^{7}$

(The Bible, Psalm 22:12,)

The $\mathrm{BwO}$ is produced when we lodge ourselves on a stratum and experiment with the opportunities it offers, when we find potential movements of deterritorialisation and produce flow conjunctions. Concepts, according to Deleuze and Guattari, should create zones of intensity and transform and mobilise thinking (1994, p. 20): "The questions is not: is it true? But: does it work? What new thoughts does it make it possible to think? What new emotions does it make it possible to feel? What new sensations and perceptions does it open in the body?" (Masumi, 2003, p. xv). As Deleuzean readings should create modes of affectivity which open new thought realignments, strange intensities and new conceptual frameworks (Grosz, 1995, p. 126-7), the grounds for the assemblage made by linking the Deleuzean notion of the body and the humoural body should ideally be thematised as experience-producing in a sensory way. My experience of embracing the humoural model is that of being reminded of the excess of life, of the fact that we are more than the finite image of self within skin that we take ourselves to be.

\section{Notes}

${ }^{1}$ The humoural model, identified with the dominant physiological paradigm of the Middle Ages and the Renaissance, makes sense of the constitution and workings of the human body in terms of its relation to four humours: black bile, yellow bile, phlegm, and blood. Each of the humours corresponds with a type of personality (sanguine, choleric, phlegmatic, melancholic), an organ (liver, spleen, lungs, gall bladder), and, most importantly, an element in nature (earth, fire, water and air.) 1 A medieval illustration of the idea can be found in Hildegard von Bingen's "Universal Man" illumination from her Liber Divinorum Operum (1165) which beautifully depicts a "Cosmic Wheel" with the osmotic connections between orbis interior and orbis exterior, the human microcosm and the universal macrocosm. On the humours, see, for instance, Gail Kern Paster, The Body Embarrassed: Drama and the Disciplines of Shame in Early Modern England; Nancy G. Sirasi, Medieval and Early Renaissance Medicine: An Introduction to Knowledge and Practice; Medicine in Seventeenth Century England, ed. Allen G. Debus.

${ }^{2}$ The grotesque body was described by Mikhail Bakhtin in his discussion of Francois Rabelais's Gargantua and Pantagruel, in which he analyses the images of medieval bodily grotesque in Rabelais in relation to its socio-political and psychological contexts of the specifically modern 
conflicts between the interior and the exterior, privacy and openness, self-containment and exchange. See: Mikhail Bakhtin, Rabelais and His World. For the link between the humoural and grotesque body, see: Paster, The Body Embarassed.

${ }^{3}$ See: Leon S. Roudiez, "Translator's Note" in Kristeva, Powers of Horror, p. viii. A similar concept is proposed by Paul Valéry in his notion of moi pure - the clear and internalised self, which comes into being as a result of negating all the external contents of the self. See: Jerrold Seigel, The Private Worlds of Marcel Duchamp: Desire, Liberation, and the Self in Modern Culture (Berkeley: University of California Press, 1995), pp. 245-246.

${ }^{4}$ Bakhtin juxtaposes the grotesque body with what he calls the classical body, embodied by a classical statue, which, devoid of openings or protuberances, keeps its distance, doesn't blur with the world and doesn't secrete any substances.

${ }^{5}$ There is a rich tradition of the revaluation of bodily fluidity in feminist writings - starting from the Cixousian (non)definition of l'écriture feminine and Luce Irigaray's fluid mechanics, through the exploration of the fluid imagery and experience in the writings of, i.e., Iris Marion Young, Elizabeth Grosz, Toril Moi, and Rosi Braidotti, to the elevation of bodily fluids in queer studies where they become one of the most crucial tropes (see, for example, the writings of Leo Bersani, Judith Halberstam, Tim Dean, Linda Williams, or Calvin Thomas. It is also worth mentioning here that the affirmative logic of the (sometimes unreflective) appropriation of abjection has become a visible trend in critical theory as well as film and art theory. The phenomenon of the so called "abject criticism" has been critically described by Winfred Menninghaus, Deborah C. Covino, and Rosalind Krauss,

${ }^{6}$ In the passage from which these quotations were extracted, Horkheimer and Adorno juxtapose the need for self-integrity with its opposition - a temptation to suspend one's boundaries and let the ego disperse, which is often portrayed as the negative reflection of modernity, or its other "dark side" manifesting itself, for instance, in the Freudian "death drive," or Bataille's notion of "inner experience."

${ }^{7}$ Stallybrass, P. and White, A., The Amplified Parallel Bible (2006), p. 668.

\section{Bibliography}

Bakhtin, M., 1984. Rabelais and His World. trans. Helene Iswolsky. Bloomington: Indiana University Press.

Barfield, O., 1957. Saving Appearances: A Study in Idolatry. New York: Harcourt Brace Jovanowich.

Bataille, G., 1989. Theory of Religion. New York: Zone Books.

Bauman, Z., 2000. Liquid Modernity. Cambridge: Polity Press.

Berman, M., 1981. The Reenchantment of the World. Ithaca and London: Cornell University Press.

Bordo, S., 1987. The Flight to Objectivity: Essays on Cartesianism and Culture. Berkeley, Los Angeles, London: University of California Press. 
Debus, Allen G., ed. 1974. Medicine in Seventeenth Century England. Berkeley: University of California Press, 1974.

Deleuze, G. and Guattari, F., 1994. What is Philopshy. London: Verso.

Deleuze, G. and Guattari, F., 2003. A Thousand Plateaus: Capitalism and Schizophrenia. Minneapolis, London: University of Minnesota Press.

Deleuze, G. and Guattari, F., 2009. Anti-Oedipus: Capitalism and Schizophrenia. New York: Penguin Classics.

Douglas, M., 2002. Purity and Danger: An Analysis of the Concepts of Pollution and Taboo. London and New York: Routledge.

Emerson, R.W., 1984. Emerson in His Journals. ed. Joel Porte, Cambridge: Belknap Press.

Ettinger. B. E., 2009. "Fragilization and Resistance," in Studies in The Maternal 1 (2) 2009, www.mamsie.bbk.ac.uk

Grosz, E., 1994. Volatile Bodies: Toward a Corporeal Feminism. Bloomington: Indiana University Press.

Grosz, E., 1995. "Refiguring Lesbian Desire", in Grosz, E. Time, Space and Perversion: Essays on the Politics of Bodies. New York: Routledge.

Horkheimer, M. and Adorno, T., 2002. Dialectic of Enlightenment: Philosophical Fragments. Ed. Noerr G. S., Stanford: Stanford University Press.

Kristeva, J., 1982. Powers of Horror: An Essay on Abjection. New York: Columbia University Press.

Masumi, B., 2003. 'Pleasures of Philosophy' Translator's Foreword to Deleuze, G. and Guattari, F. (2003) A Thousand Plateaus. Capitalism and Schizophrenia. Minneapolis, London: University of Minnesota Press.

Paster, G. K., 1993. The Body Embarrassed: Drama and the Disciplines of Shame in Early Modern England. Ithaca, New York: Cornell University Press.

Roudiez, L.S., 1982. "Translator's Note' in Kristeva, J. Powers of Horror: An Essay on Abjection. New York: Columbia University Press.

Seigel, J., 1995. The Private Worlds of Marcel Duchamp: Desire, Liberation, and the Self in Modern Culture. Berkeley: University of California Press.

Nancy G. Sirasi, 1990. Medieval and Early Renaissance Medicine: An Introduction to Knowledge and Practice. Chicago: University of Chicago Press.

Stallybrass, P. and White, A., 1986. The Politics and Poetics of Transgression. London: Methuen.

Stallybrass, P. and White, A., 2006. The Amplified Parallel Bible. Peabody: Hendrickson Publishers.

Vigarello, G. , 2005). Le propre et le sale. L'hygiène du corps depuis le Moyen Âge, Paris: Éditions de Seuil. 